\title{
EVALUATION OF COTTON (GOSSYPIUM SPP.) GERMPLASM FOR HEAT TOLERANCE UNDER NORMAL AND LATE PLANTING TIME
}

\author{
Emine KARADEMIR ${ }^{1, *}$, C. KARADEMIR ${ }^{1}$, B. KOLAY ${ }^{2}$, \\ V. SEZENER ${ }^{3}$, H. BASAL ${ }^{4}$ \\ *E-mail: eminekarademir@siirt.edu.tr
}

Received: July 09, 2020. Revised: July 21, 2020. Accepted: Aug. 10, 2020. Published online: Oct. 16, 2020

\begin{abstract}
The objective of this study was to determine cotton (Gossypium ssp.) germplasm for heat tolerance under normal and late planting time. For this aiming 200 cotton genotypes and five check varieties (Gloria, SG 125, Flash, Ozbek 105 and Candia) were evaluated under two different temperature regimes and experiments were conducted according to the augmented design with four blocks. Field studies were carried out at the GAP International Agricultural Research and Training Center's experimental area in Diyarbakır, Turkey, in 2016 cotton growing season. In the study heat susceptibility index was used for discriminate to the genotypes for heat tolerance. Genotypes were classified into four groups based on the heat susceptibility index. The results of this study indicated that five cotton genotypes (TAM 139-17 ELS, CIM-240, Haridost,
\end{abstract}

MNH-990 and AzGR-11835) were in highly heat tolerant, 28 genotypes were found heat tolerant, 56 genotypes were in the moderately heat tolerant and other 120 genotypes were observed susceptible for heat tolerance. Based on the heat susceptibility index, five cotton genotypes can be used as parent for heat tolerance improvement in the cotton breeding program where high temperature is a limiting factor for seed cotton yield.

Keywords: cotton; abiotic stress; susceptibility; resistance; yield.

\section{INTRODUCTION}

High temperature stress is an important abiotic stress factor, which limiting plant growth and productivity worldwide is expected to increase in

\footnotetext{
${ }^{1}$ Siirt University Faculty of Agriculture Department of Field Crops, Siirt/Turkey

${ }^{2}$ GAP International Agricultural Research and Training Center, Diyarbakir, Turkey

${ }^{3}$ Cotton Research Institute, Nazilli, Turkey

${ }^{4}$ Adnan Menderes University, Faculty of Agriculture, Department of Field Crops, Aydın, Turkey
} 
the future. High temperature stress causes some morphological, physiological, biochemical and molecular changes that adversely affect plant growth and yield (Liakatas et al., 1998; Singh et al., 2007; Yıldız and Terzioğlu, 2007; Zhang et al., 2016; Bhattacharya, 2019). Heat stress usually occurs in conjunction with other environmental stresses such as drought and high light intensity that aggravate the impact in terms of low plant population per unit area, reduced fiber yield and quality of cotton fiber (Rahman, 2006; Khan et al., 2008).

Cotton is a plant of warm climate origin, but it is damaged by extremely high temperatures during the growing period (Oosterhuis, 2002). The optimum temperature for cotton growth is reported to be between 20 to $30^{\circ} \mathrm{C}$. (Reddy et al., 1991). High temperature above $36^{\circ} \mathrm{C}$ affects plant growth and development, especially during the reproductive phase and effect pollination, fertilization and another physiological process. Indeed, higher temperatures affect all stages of growth and development of cotton, but the crop sensitivity to adverse temperatures seems to increase during reproductive development (Phillips, 2012). Reddy et al. (1991) revealed that cotton plants became less reproductive at $35 / 27^{\circ} \mathrm{C}$ and lost their reproductive ability at $40 / 32^{\circ} \mathrm{C}$. High temperature stress can negatively affect the plant height, number of nodes and internodes and number of monopodial and sympodial branches (Roussopoulos et al., 1998).
Excessively high temperatures can decrease other important traits, such as seed size, fibers per seed, and fiber length (Oosterhuis, 1999), boll number, boll retained and boll retention percentage (Hake and Silvertooth, 1990; Reddy et al., 1992; Lokhande and Reddy, 2014) and boll size and maturation period (Reddy et al., 1999; Zafar et al., 2018), leaf area expansion or dry weight accumulation (Roussopoulos et al., 1998), root and shoot development (Abro et al., 2015; Farooq et al., 2015). Wells and Stewart (2009) observed that the greatest stem elongation, leaf area expansion and dry weight accumulation was occurred at $30 / 22^{\circ} \mathrm{C}$, with less growth at both lower and higher temperature regimes. On the other hand, Pettigrew (2008) reported that warm temperature regime was consistently $3 \%$ stronger than fiber in the control, but lint yield from the warm regime was $10 \%$ lower than that of control. Timing, duration and intensity of heat stress might affect the ability to screen for heat tolerance. The flowering time is the most sensitive period to high temperature on the cotton plant.

One of the most important and economic ways to overcome the negative effects of heat stress is to identify or develop heat-tolerant cotton cultivars (Sing et al., 2007). Breeding temperature tolerant cultivars would be a sustainable and cheapest approach to get good produce under extreme temperature situation (Zafar et al., 2018). Bibi (2006) observed that cotton plant 


\section{EFFECTS OF HIGH TEMPERATURE ON SEED COTTON YIELD}

started showing signs of stress between $35^{\circ} \mathrm{C}$ and $38^{\circ} \mathrm{C}$ and screened some cotton genotypes for heat tolerance and reported that Acala Maxxa, SG215 BR and DP 4444BG/RR were the most tolerant genotypes to high temperatures, and suggested use of wild germplasm and screening under controlled conditions for heat tolerance studies.

At present, the major constraint for identifying heat-tolerant cultivars is the lack of reliable screening tools. A better understanding of the possible impact of high-temperature stress on physiological, morphological, and yield processes would not only help in mitigating the adverse effects of hightemperature stress, but also in developing reliable field-screening tools (Sing et al., 2007). One of these methods is to compare the genotypes by sowing at two different times for yield differences.

The present study was carried out to determine the effects of high temperature on seed cotton yield and also to assess the tolerance of 205 cotton genotypes to heat stresses based on heat susceptibility index.

\section{MATERIALS AND METHODS}

Field experiments were conducted during the 2016 cotton growing season at the GAP International Agricultural Research and Training Center $\left(37^{\circ} 56^{\prime} \mathrm{N}\right.$ Lat, $40^{\circ} 15^{\prime} \mathrm{E}$ Long and $677 \mathrm{~m}$ elevation) in Diyarbakir, Turkey. The climate in this region is semiarid with total annual precipitation of $549.1 \mathrm{~mm}$ (Anonymous, 2017). Long term climatical findings showed that there were $454 \mathrm{~mm}$ total rainfall and $15.8^{\circ} \mathrm{C}$ average temperature in every year. The research soils are zonal soils, which are generally red-brown and included in the big soil group having a clayish nature, flat or about to be flat, having very small erosion and deep or medium deep. The soil samples were taken from 0-30 cm depth and analyzed at GAP International Agricultural Research Institute's laboratory and it had loamy structure, slightly alkali, limy and salty, poor in terms of organic matter and phosphorus and sufficient for potassium.

The genetic material used in this study consisted of 200 cotton genotypes and five control varieties (Gloria, SG 125, Flash, Ozbek 105 and Candia). Two field experiments were conducted under normal and high temperature stress conditions. By conducted two sowing time experiments, the plant's flowering period coincided with two different temperatures. The experiments were laid out in an augmented design with four blocks and formed from a total of 220 parcels (each block consisted of 50 genotypes and five controls).

Each plot consisted of 1 row with $12 \mathrm{~m}$ long and the distance between and within rows were $70 \mathrm{~cm}$ and $15 \mathrm{~cm}$, respectively. Sowing was made with the machine under optimum sowing condition (timely sown, 29 April 2016), and high temperature stress condition was planted (late sown planting, 24 May 2016), all plots received $140 \mathrm{~kg} \mathrm{ha}^{-1} \mathrm{~N}$ and $60 \mathrm{~kg} \mathrm{ha}^{-1}$ $\mathrm{P}_{2} \mathrm{O}_{5}$. Half of the nitrogen and all phosphorus were applied at sowing time and the remaining $\mathrm{N}$ was given as ammonium nitrate $(33 \%)$ at the squaring stage before the first irrigation. Recommended cultural practices, such as insect and weed control methods, were employed from sowing to harvesting of the cotton crop and furrow irrigation was applied at six times, in late planting time 
irrigation was needed for seed germination for this reason irrigation was done just after sowing. Insects were applied two times for Thrips tabaci and Empoasca ssp. during the cotton vegetation period.

The plots were harvested twice by hand for yield determination on 27 September 2016 and second on 11 October 2016 in the first sowing time and 28 October 2016 and 15 November 2016 in the second sowing time and after completed harvesting seed cotton weight were weighed and calculated for seed cotton yield. To determine the severity of high temperature stress, the hobo instrument was placed in the experimental area and the temperature and humidity values were recorded hourly intervals (Fig. 1). As shown in the Fig. 1, it can be seen that in the Diyarbakir province temperature can reach at $55.5^{\circ} \mathrm{C}$.

\section{Statistical analysis}

Statistical analyses of data were performed using the JMP 7.0.1 statistical software package program (SAS Institute, 2002), and the heat susceptibility index (HSI) was calculated with formula, as shown below, according to Ficher and Maurer (1978). The high temperature yield data and lower temperature yield data from the trials in this study were used in place of the genotypic mean values for yield under stress $(\mathrm{Y})$ and potential yield under non-stress (Yp) variables, respectively, in the equations for the above indices. $\mathrm{X}$ and $\mathrm{Xp}$ are the mean yield of all genotypes per trial under stress and non-stress conditions. Higher HSI indicates greater susceptibility.

\section{Heat susceptibility index (HSI):} $(1-Y / Y p) /(1-X / X p)$

$Y$ : Seed cotton yield of genotype in a stress environment; Yp: Seed cotton yield of genotype in a stress free environment;
$X$ : Mean $Y$ of all genotypes; Xp: Mean Yp of all genotypes.

In this formula: $\mathrm{HSI}=<0.50=$ Highly tolerant; $\mathrm{HSI}=0.51-0.75=$ Heat tolerant; $\mathrm{HSI}=0.76-1.00=$ Moderate heat tolerant; $\mathrm{HSI}=>1.00=$ Heat susceptible.

\section{RESULTS AND DISCUSSION}

According to Augmented experimental design, the results of the seed cotton yield of the genotypes obtained from an experiment carried out in two different sowing times under field conditions are shown in the Table 1. As can be seen, the seed cotton yield of late planting time decreased. The comparative yield values of two sowing time of 205 cotton genotypes (200 lines + five check varieties) can be seen in Fig. 1.

Seed cotton yield of normal sowing time genotypes changed from $969.70 \mathrm{~kg} \mathrm{ha}^{-1}$ to $5911.90 \mathrm{~kg} \mathrm{ha}^{-1}$. The highest yield obtained from B-557 (5911.90 $\mathrm{kg} \mathrm{ha}^{-1}$ ), while the lowest yield obtained from Giza 7 line $\left(969.70 \mathrm{~kg} \mathrm{ha}^{-1}\right)$ under normal planting time. At normal sowing time among five control varieties the highest seed cotton yield obtained from Ozbek 105 (4714.30 $\mathrm{kg} \mathrm{ha}^{-1}$ ), while the lowest yield obtained from SG 125 (2398.90 $\left.\mathrm{kg} \mathrm{ha}^{-1}\right)$.

Seed cotton yield of late sowing time genotypes changed from $344.60 \mathrm{~kg} \mathrm{ha}^{-1}$ to $3316.10 \mathrm{~kg} \mathrm{ha}^{-1}$. The highest yield obtained from Haridost (3316.10 $\mathrm{kg} \mathrm{ha}^{-1}$ ), while the lowest yield obtained from Acala 3080 line (344.60 $\mathrm{kg} \mathrm{ha}^{-1}$ ) under late planting time. At late sowing time among, five control varieties the highest seed 


\section{EFFECTS OF HIGH TEMPERATURE ON SEED COTTON YIELD}

cotton yield obtained from Ozbek 105 $\left(2094.00 \mathrm{~kg} \mathrm{ha}^{-1}\right)$, while the lowest yield obtained from Candia (755.80 kg ha ${ }^{-1}$ ). High seed cotton yield of a genotype under late sown condition indicated the presence of genes for heat tolerance.

Table 1 - Seed cotton yield of genotypes under normal and late planting time

\begin{tabular}{lcc}
\hline & Normal planting time $\left.\mathbf{( k g ~ h a}{ }^{-1}\right)$ & Late planting time $\left.\mathbf{~} \mathbf{k g ~ h a} \mathbf{~}^{-1}\right)$ \\
\hline The highest line & 5911.90 & 3316.10 \\
\hline The lowest line & 969.70 & 344.60 \\
\hline Mean of lines & 3284.80 & 1063.00 \\
\hline The highest control & 4714.30 & 2094.00 \\
\hline The lowest control & 2398.90 & 755.80 \\
\hline Mean of controls & 3176.00 & 1112.10 \\
\hline General mean & 3282.36 & 1167.99 \\
\hline CV $(\%)$ & 12.31 & 31.66 \\
\hline LSD $(0.05)$ & $123.73^{*}$ & $\mathrm{~ns}$ \\
\hline
\end{tabular}

ns: non significant; * and **, significantly different from zero at $p \leq 0.05$ and $p \leq 0.01$, respectively.

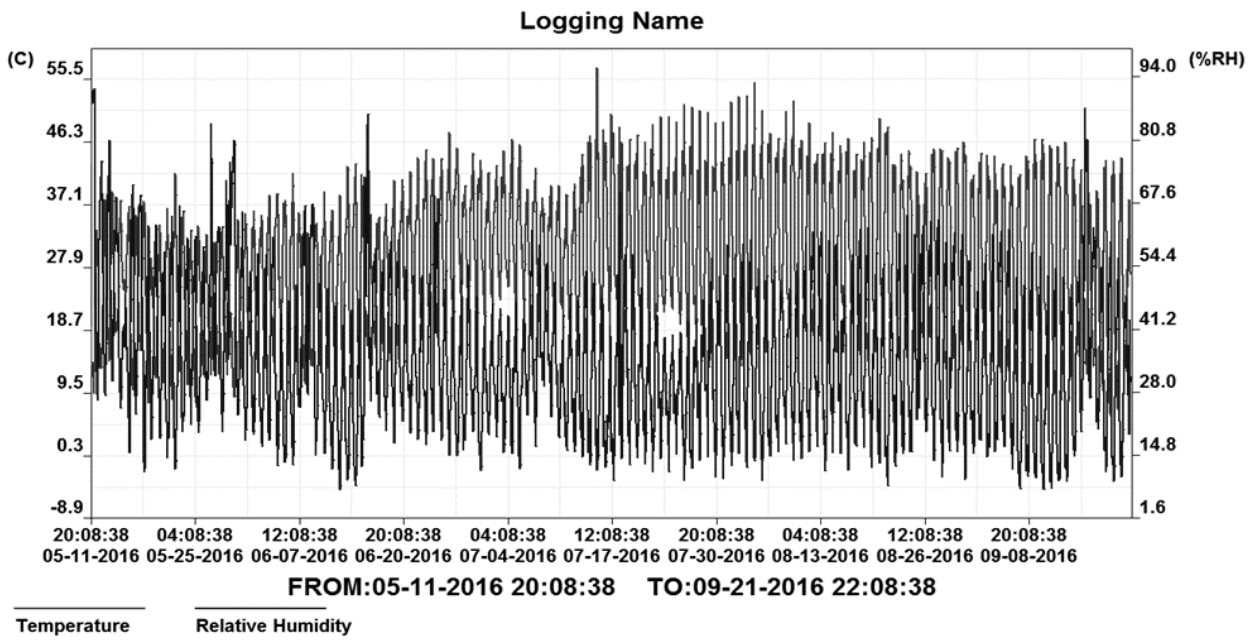

Figure 1 - Meteorological data on daily minimum, maximum temperature and relavite humidity

When the general mean of the experiment is examined, it is seen that the seed cotton yield is $3282.36 \mathrm{~kg} \mathrm{ha}^{-1}$ at normal sowing time and $1167.99 \mathrm{~kg}$ $\mathrm{ha}^{-1}$ at late sowing time. The one month difference in sowing time led to a $35.58 \%$ reduction in average yield values (Table 1). Similar findings have been revealed by Pettigrew (2008), who previously reported that lint yield from the warm regime was $10 \%$ lower than that of the control and yield reduction was primarily caused by a $6 \%$ smaller boll 
mass, with $7 \%$ fewer seed produced per boll in the warm regime. Negative correlations between high temperature and cotton yield reported by Oosterhuis (1999), Oosterhuis (2011) and Zahid et al. (2016).

Cotton genotypes in the experiment were classified according to high temperature stress sensitivity index according to the seed cotton yield values under normal and late sowing conditions and four different groups were formed. It was determined that five cotton genotypes (TAM 139-17 ELS, CIM-240, Haridost, MNH-990 and AzGR-11835) showed a highly significant tolerance to high temperature stress and their high temperature sensitivity index values were less than 0.50 .

Among the genotypes, 28 cotton genotypes were tolerant to high temperature stress (TAM 04 WB 33S, TAM B147-21-ELS, TAM B182-33ELS, Acala Okra VA2-4, Acala Tex, Deltapine 14, AzGR-7711, Mex 123, Taaskent, Tex 2382, Darmi, Helius, NIAB-111-1, Ujchi 2 Uzbek, Viky (ES-20021), Ziroatkar-68, BH-118, CIM-506, CRI5-134, Malmal-MNH786, Korina, MNH-786 7, MNH-814, Shahbaz, Rantos, Frego Cluster and Giza 7). High temperature sensitivity index values of these genotypes ranged from 0.51 to 0.75 .

It was seen that from the Table 2, 52 genotypes were found to be moderately tolerant to high temperature stress. Ozbek 110 control variety was also included in this group (Table 2). High temperature sensitivity index values of genotypes in this group ranged between 0.761.00. Cotton genotypes in this group (TAM 87-G3-27, TAM 94 L 25, TAM A 106-16 ELS, TAM C147-42ELS, TAM C66-26-ELS, Acala-1064, Acala 1-13-3 -1, Acala 1517-70, Acala 1517-91, Acala 29, Acala 442, Acala Cluster, Acala Morell, Acala Okra, Deltapine 15, Deltapine 15A, Deltapine 714 GN, Deltapine 905, Dpl-5540-85-subokra, Giza 59, TAMCOT SPHINX, Karnak 55, New MexicanAcala, Stoneville 213, Stoneville 256-315, Stoneville 2B, Stoneville-3202, Stoneville 5A, Tadla 25, Tex 843, Eva, Ligur, Mehigon, NIAB 777, NIAB 874, MNH 493, Sugdion-2, AzGR-3775, Ziroatkar-81, 173/994, CIM-401, CIM-70, CRI5342, FH 142, NIAB-KIRN, Acala Nakad, Alba Acala 70, Samos, Nova, AzGR-11468, AGC 85, Özbek105 (Control 4) can be said to have moderate tolerance to high temperature.

It was seen that 120 genotypes, which made up the majority of the experiment, were sensitive to high temperature stress. It was determined that Gloria, SG 125, Flash and Candia control varieties were included in this group. High temperature sensitivity of genotypes in this group was found to be greater than 1.00 .

Many researchers tested different cotton varieties against for high temperature, some of these studies were carried out under field conditions and others under controlled conditions. Ashraf et al., (1994) screened response of five cotton cultivars of cotton (Gossypium 


\section{EFFECTS OF HIGH TEMPERATURE ON SEED COTTON YIELD}

hirsutum L.) B-557, CIM-70, MNH93, NIAB-78 and S-12 to high temperature stress and assessed at germination and a later growth stage under controlled environmental conditions and they reported that all five cultivars did not germinate at $50^{\circ} \mathrm{C}$, B-557 and $\mathrm{MNH}-93$ had relatively higher percentage germination at $40^{\circ} \mathrm{C}$ than the other cultivars.

\section{Table 3 - Classification of genotypes according}

to their sensitivity to high temperature

\begin{tabular}{|c|c|c|c|c|}
\hline $\begin{array}{l}\text { Highly heat } \\
\text { tolerant }\end{array}$ & $\begin{array}{l}\text { Heat } \\
\text { tolerant }\end{array}$ & $\begin{array}{l}\text { Moderately heat } \\
\text { tolerant }\end{array}$ & Heat susceptible & \\
\hline $\begin{array}{l}\text { TAM 139-17 } \\
\text { ELS }\end{array}$ & $\begin{array}{l}\text { TAM } 04 \text { WB } \\
33 S\end{array}$ & TAM 87-G3-27 & TAM 01 E 22 & Tex 1216 \\
\hline CIM-240 & $\begin{array}{l}\text { TAM B147- } \\
21-E L S \\
\end{array}$ & TAM 94 L 25 & $\begin{array}{l}\text { TAM C 155-22 } \\
\text { ELS }\end{array}$ & Tex 2167 \\
\hline Haridost & $\begin{array}{l}\text { TAM B182- } \\
\text { 33-ELS }\end{array}$ & $\begin{array}{l}\text { TAM A 106-16 } \\
\text { ELS }\end{array}$ & TAM C66-16- ELS & Tex 844 \\
\hline MNH-990 & $\begin{array}{l}\text { Acala Okra } \\
\text { VA2-4 }\end{array}$ & $\begin{array}{l}\text { TAM C147-42- } \\
\text { ELS }\end{array}$ & $\begin{array}{l}\text { TAM C66-266- } \\
\text { ELS }\end{array}$ & Tex 1389 \\
\hline \multirow[t]{19}{*}{ AzGR-11835 } & Acala Tex & TAM C66-26-ELS & Acala 1517C & Tex 1412 \\
\hline & Deltapine 14 & Acala-1064 & Acala $1517 \mathrm{D}$ & Tex 1416 \\
\hline & AzGR-7711 & Acala 1-13-3-1 & $\begin{array}{l}\text { Acala } 1517 \text { SR2 - } \\
\text { vert }\end{array}$ & Tex 2383 \\
\hline & Mex 123 & Acala 1517-70 & Tropikal 225 & Tex 2700 \\
\hline & Taaskent & Acala 1517-91 & Acala 3080 & Acala \\
\hline & Tex 2382 & Acala 29 & Acala 32 & $\begin{array}{l}\text { Africa E5 } \\
(20025)\end{array}$ \\
\hline & Darmi & Acala 442 & Acala 44 & Agala Sindou \\
\hline & Helius & Acala Cluster & Acala-44-WR & Arrota- 129 \\
\hline & NIAB 111 & Acala Morell & Acala 4-42 & Avesto \\
\hline & $\begin{array}{l}\text { Ujchi } 2 \\
\text { Uzbek }\end{array}$ & Acala Okra & Acala 51 & Bulgar 6396 \\
\hline & $\begin{array}{l}\text { Viky (ES- } \\
20021)\end{array}$ & Deltapine 15 & Acala 8 & Bulgar 73 \\
\hline & Ziroatkar-68 & Deltapine 15A & Acala Glandless & Campu \\
\hline & $\mathrm{BH}-118$ & Deltapine 714 GN & Acala Harper & $\begin{array}{l}\text { Carolina } \\
\text { Queen }\end{array}$ \\
\hline & CIM-506 & Deltapine 905 & $\begin{array}{l}\text { Acala } \\
\text { MexicanLindless }\end{array}$ & Cascot L7 \\
\hline & CRI5-134 & $\begin{array}{l}\text { Dpl-5540-85- } \\
\text { subokra }\end{array}$ & Acala N 28-5 & Deltapine 20 \\
\hline & $\begin{array}{l}\text { Malmal- } \\
\text { MNH-786 }\end{array}$ & Giza 59 & Acala Nunn's & Deltapine 50 \\
\hline & Korina & TAMCOT SPHINX & $\begin{array}{l}\text { Acala Shafter } \\
\text { Station }\end{array}$ & $\begin{array}{l}\text { Deltapine } \\
565\end{array}$ \\
\hline & MNH-786 & Karnak 55 & Acala SJ1 & $\begin{array}{l}\text { Deltapine- } \\
5816\end{array}$ \\
\hline & MNH-814 & $\begin{array}{l}\text { New } \\
\text { MexicanAcala }\end{array}$ & Acala SS-2280 & Europa \\
\hline
\end{tabular}


Emine KARADEMIR, C. KARADEMIR, Betül KOLAY, V. SEZENER, H. BASAL

\begin{tabular}{|c|c|c|c|}
\hline Shazbaz & Stoneville 213 & Acala Young's & $\begin{array}{l}\text { Fibermax } \\
819\end{array}$ \\
\hline Rantos & Stoneville 256-315 & Acala $55-5$ & $\begin{array}{l}\text { Fibermax } \\
832\end{array}$ \\
\hline $\begin{array}{l}\text { Frego } \\
\text { Cluster }\end{array}$ & Stoneville 2B & Aden & Giza 70 \\
\hline Giza 7 & Stoneville-3202 & Auborn 56 & Giza 75 \\
\hline AzGR-11836 & Stoneville $5 \mathrm{~A}$ & Deltapine 12 & Tonia \\
\hline & Tadla 25 & Crumpled & NIAB 78 \\
\hline & Tex 843 & Brown Egyptian & NIAB 846 \\
\hline & Eva & Deltapine 120 & Penta \\
\hline & Ligur & Deltapine 25 & Sivon \\
\hline & Mehigon & Deltapine 26 & Sarbon \\
\hline & NIAB 777 & Deltapine 41 & $\begin{array}{l}\text { Stonoville } \\
474\end{array}$ \\
\hline & NIAB 874 & Deltapine 45 Vert & $\begin{array}{l}\text { Stonoville } \\
506\end{array}$ \\
\hline & MNH 493 & Deltapine 50 & AZGR-11839 \\
\hline & Sugdiyon-2 & Deltapine 61 & $\begin{array}{l}\text { Sure Grow- } \\
125\end{array}$ \\
\hline & AzGR-3775 & Deltapine 62 & Zeta 2 \\
\hline & Ziroatkar-81 & Deltapine 80 & Ziroatkar-64 \\
\hline & $173 / 994$ & Deltapine SR-4 & B557 \\
\hline & CIM-401 & Deltapine SR-5 & Marvi \\
\hline & CIM-70 & Deltapine Staple & NIAB-111-1 \\
\hline & CRI5-342 & Earlipima & NIA-UFAQ \\
\hline & $\mathrm{FH} 142$ & Giza 45 & AGDAŞ 3 \\
\hline & NIAB-KIRN & Giza 83 & Sadori \\
\hline & Acala Nakad & Hopicala Vert & Sindh-1 \\
\hline & Alba Acala 70 & Stoneville 014 & Sohni \\
\hline & Samos & Mex 122 & $\mathrm{VH} 260$ \\
\hline & Nova & Mex 68 & Aboriginal 79 \\
\hline & AzGR-11468 & Mex 106 & AzGR-11834 \\
\hline & AGC 85 & Mex 102 & NIBGE-2 \\
\hline & $\begin{array}{l}\text { Özbek105 (Control } \\
\text { 4) }\end{array}$ & Stoneville 256 & Ağdaş 7 \\
\hline & & Stoneville 3 & Ağdaş 6 \\
\hline & & Stoneville 508 & Ağdaş 17 \\
\hline & & $\begin{array}{l}\text { Stoneville } 618 \\
\text { BBR }\end{array}$ & AGC 208 \\
\hline & & Stoneville 62 & AGC 375 \\
\hline & & Stoneville $731 \mathrm{~N}$ & $\begin{array}{l}\text { Gloria } \\
\text { (Control 1) }\end{array}$ \\
\hline & & Stoneville 108 SR & $\begin{array}{l}\text { SG125 } \\
\text { (Control 2) }\end{array}$ \\
\hline & & Stoneville 504 & $\begin{array}{l}\text { Flash } \\
\text { (Control 3) }\end{array}$ \\
\hline & & Tex 1152 & $\begin{array}{l}\text { Candia } \\
\text { (Control 5) }\end{array}$ \\
\hline
\end{tabular}


Abro et al. (2015) studied 58 newly evolved cotton genotypes to heat stresses under field conditions and two different temperature regimes based on agronomic and physiological characteristics and they used heat tolerance index. Authors revealed that 17 genotypes (NIA-80, NIA-81, NIA83, NIA-84, NIA-M-30, NIA-M31, NIA-HM-48, NIA-HM-327, NIA-H32, NIA-HM-2-1, NIA-Bt1, NIA-Bt2, NIA-Perkh, CRIS-342, CRIS-134, NIAB-111-1) and check variety Sadori indicated a high level of heat tolerance at both (heat-stressed and non-stressed) temperature regimes. Zhang et al. (2016) also studied some cotton cultivars for heat tolerance and reported that VH 260 and MNH 456 cotton variety as heat tolerant and ST 213 and ST 4288 as heat susceptible. Singh et al. (2018) revealed using on the cumulative heat stress response index (CHSRI) classified five cotton cultivars as heat tolerant (UA 48, MON11R124B2R2, MON11R112B2R2, PHY36WRF and PX532211WRF), while 18 and 15 cotton cultivars as intermediate and heat-sensitive. Salman et al. (2019) studied 80 accessions of cotton for heat tolerance using relative cell injury (RCI) and they reported that FH-142 and VH-282 as desirable parents for utilization breeding programs for the development of heat tolerant germplasm.

The varieties observed in this study were planted in two different sowing times under field conditions and it was ensured that the varieties encountered different temperature degrees at flowering periods and yield performance of these varieties was compared. The tolerance of varieties against high temperature was determined by using only the heat tolerance index. The data obtained from this study is thought to be important for cotton breeding studies.

\section{CONCLUSIONS}

In this study, genotypic differences determined for the heat tolerance based on the seed cotton yield in two different sowing times. Late planting time resulted in decreased seed cotton yield and an average $35 \%$ yield decreases observed. It was determined that 120 of 205 genotypes were sensitive to temperature, 52 genotypes were found moderately heat tolerant, 28 genotypes were found heat tolerant and five genotypes (TAM 139-17 ELS, CIM-240, Haridost, MNH-990 and AzGR-11835) were found highly heat tolerant. These five cotton genotypes can be used as parent for heat tolerance improvement in the cotton breeding program where high temperature is a limiting factor for seed cotton yield. Among the control varieties, only Ozbek 105 control variety exhibited high temperature tolerance, the others were found sensitive. The results of this study were obtained from the results of a one-year field trials, the responses of genotypes may not be performing very well and may not be the same everywhere. However, in this study large genetic material screened and 
during the cotton growing period high temperature reached $>50^{\circ} \mathrm{C}$ and significant yield reduction occurred.

Acknowledgements. This study was supported by the Scientific and Technical Research Council of Turkey (TUBITAK) under Grant No. TOVAG-214O074. We wish to thanks TUBITAK for their financial support.

\section{REFERENCES}

Abro, S., Rajput, M.T., Khan, M.A., Sial, M.A. \& Tahir, S.S. (2015). Screening of cotton (Gossypium hirsutum L.) genotypes for heat tolerance. Pak.J.Bot., 47(6): 20852091.

Anonymous (2017). General Directorate of Meteorology. Available: https://www.mgm.gov.tr/FILES/arasti rma/yagis-degerlendirme/2016-2017 alansal.pdf

Ashraf, M., Saeed, M.M. \& Qureshi, M.J. (1994). Tolerance to high temperature in cotton (Gossypium hirsutum L.) at initial growth stages. Environ.Exp. Bot., 34(3): 275-283, DOI: 10.1016/ 0098-8472(94)90048-5

Bhattacharya, A. (2019). Effect of high temperature on crop productivity and metabolism of macromolecules. Available: https://www.elsevier.com/ books/effect-of-high-temperature-oncrop-productivity-and-metabolism-ofmacro-molecules/bhattacharya/9780-12-817562-0

Bibi, A. (2006). Heat stress on physiology and biochemistry of diverse cotton germplasm. Available: http://crops. confex.com/crops/2006srb/techprogr am/P13590.HTM

Farooq, J., Mahmood, K., Akram, M.W., Rehman, A., Javaid, M.A., Petrescu-Mag, V. \& Nawaz, B. (2015). High temperature stress in cotton Gossypium hirsutum L. ELBA Bioflux, 7(1): 34-44.
Fisher, R.A. \& Maurer, R.A. (1978). Drought resistance in spring wheat cultivars. I. Grain yield responses. Aust.J.Agric.Res., 29(5): 897-912, DOI: 10.1071/AR9780897

Hake, K. \& Silvertooth, J. (1990). High temperature effects on cotton. Physiology today. Newsletter of the Cotton Physiology Education Program. https://www.cotton.org/tec h/physiology/cpt/plantphysiology/upl oad/CPT-July90-REPOP.pdf

Khan, A.I., Khan, I.A. \& Sadaqat, H.A. (2008). Heat tolerance variable in cotton (Gossypium hirsutum L.) and can be exploited for the breeding of better yielding cultivars under high temperature regimes. Pak.J.Bot., 40(5): 2053-2058.

Liakatas, A.L., Roussopoulos, D. \& Whittington, W.J. (1998). Controlled-temperature effects on cotton yield and fibre properties. J.Agric.Sci., 130(4): 463-471, DOI: 10.1017/S00 21859698005413

Lokhande, S. \& Reddy, K.R. (2014). Quantifying temperature effects on cotton reproductive efficiency and fiber quality. Agron.J., 106(4): 1275, DOI: 10.2134/agronj13.0531

Oosterhuis, D.M. (1999). Yield response to environmental extremes in cotton. Proceedings of the Cotton Research Meeting Summary Cotton Research in Progress. Special Report 193. Arkansas Agric. Exp. Stat., Fayetteville, AR, pp. 30-38.

Oosterhuis, D.M. (2002). Day or night high temperature. A major cause of yield variability. Cotton Grower, 46: 8-9.

Oosterhuis, D.M. \& Snider, J.L. (2011). High temperature stress on floral development and yield of cotton. Stress physiology in cotton. The Cotton Foundation Reference Book Series, Chapter 1, p. 1.

Pettigrew, W.T. (2008). The Effect of higher temperatures on cotton lint yield production and fiber quality. Crop Sci., 48: 278-285, DOI: 10.21 35/cropsci2007.05.0261 


\section{EFFECTS OF HIGH TEMPERATURE ON SEED COTTON YIELD}

Phillips, J.B. (2012). Cotton response to high temperature stress during reproductive development. MSc. Thesis, Available: http://scholarwo rks.uark.edu/etd/394

Rahman, H. (2006). Number and weight of cotton lint fibers: variation due to high temperatures in the field. Aust.Agric.Res., 57(5): 583-590, DOI: 10.1071/AR05135

Roussopoulos, D., Liakatas, A. \& Whittington, W.J. (1998). Controlled-temperature effects on cotton growth and development. J.Agric.Sci., 130: 451-462, DOI: 10.1017/S0021859698005401

Reddy, K.R., Hodges, H.F., McKinion, J.M. \& Wall, G.W. (1991). Temperature effects on Pima cotton growth and development. Agron.J., 84(2): 237-243, DOI: 10.2134/agronj 1993.00021962008500030030x

Reddy, K.R., Hodges, H.F. \& Reddy, V.R. (1992). Temperature effects on cotton fruit retention. Agron.J., 84(1): 26-30, DOI: 10.2134/agronj 1992.00021962008400010006x

Reddy, K.R., Davidonis, G.H., Johnson, A.S. \& Vinyard, B.T. (1999). Temperature regime and carbon dioxide enrichment alter cotton boll development and fiber properties. Agron.J., 91(5): 851-858, DOI: 10.21 34/agronj1999.915851x

Salman, M., Zia, U.Z., Rana, I.A., Maqsood, R.H., Ahmad, S., Bakhsh, A. \& Azhar, M.T. (2019). Genetics effects conferring heat tolerance in upland cotton (Gossypium hirsutum L.). J. Cotton Res., 2(1): 2-9, DOI: 10.1186/s42 397-019-0025-2

Statistical Analysis System (SAS) Institute (2002). SAS/STAT User's Guide. Version 8, 6th Edition, SAS Institute, Cary, 112.

Singh, R.P., Prasad, P.V.V., Sunita, K., Giri, S.N. \& Reddy, K.R. (2007). Influence of high temperature and breeding for heat tolerance in cotton: a review. Adv.Agron., 93: 313-385, DOI: $10.1016 /$ S0065-2113(06)9300 6-5

Singh, K., Wijewardana, C., Gajanayake, B., Lokhande, S., Wallace, T., Jones, D. \& Reddy, K.R. (2018). Genotypic variability among cotton cultivars for heat and drought tolerance using reproductive and physiological traits. Euphytica, 214(57): 2-22, DOI: $10.1007 / \mathrm{s} 106$ 81-018-2135-1

Wells, R. \& Stewart, A.M. (2009). Morphological alterations in response to management and the environment. Physiology in cotton, 23-32. https://li nk.springer.com/chapter/10.1007\%2 F978-90-481-3195-2_3

Yıldız, M. ve Terzioğlu, Y. (2007). Yüksek Sıcaklık Stresinde Bitki Sıcaklık Şoku Proteinlerinin Rolü. Anadolu Ûniversitesi Bilim ve Teknoloji Dergisi, 8(1): 21-39.

Zafar, S.A., Noor, M.A., Waqas, M.A., Wang, X., Shaheen, T., Raza, M. \& Ur-Rahman, M. (2018). Temperature extremes in cotton production and mitigation strategies, DOI: 10.5772/ intechopen.74648. In: Rahman M.U., Zafar Y. (Eds.), Past, Present and Future Trends in Cotton Breeding, IntechOpen, Rijeka, https://www.inte chopen.com/books/past-present-and -future-trends-in-cotton-breeding/tem perature-extremes-in-cotton-producti on-and-mitigation-strategies

Zahid, K.R., Ali, F., Shah, F., Younas, M., Shah, T. \& Wu, W. (2016). Response and tolerance mechanism of cotton Gossypium hirsutum L. to elevated temperature stress: a review. Front. Plant Sci., 7: 937, DOI: 10.3389/fpls.2016.00937

Zhang, J., Srivastava, V., Stewart, J.M. \& Underwood, J. (2016). Heattolerance in cotton is correlated with induced overexpression of heatshock factors, heat-shock proteins, and general stress response genes. J. Cotton Sci., 20(3): 253-262. 